\title{
Krzysztof Dubiński
}

krzysztof.dubinski@poczta.fm

\section{Jose Arturo Castellanos, George Mantello i salwadorskie certyfikaty}

\begin{abstract}
„Dzięki certyfikatom obywatelstwa Republiki Salwadoru wydanym przez jej urzędników - konsula generalnego José Artura Castellanosa i pierwszego sekretarza konsulatu George'a Mandel-Mantella udało się uratować życie od 25 do 30 tys. Żydów. To nieopowiedziana jeszcze historia o tym, jak jeden z najmniejszych krajów świata ułatwił jedną z najbardziej udanych akcji ratunkowych drugiej wojny światowej" - taka zapowiedź towarzyszyła filmowi dokumentalnemu Brada Marlowe'a Glass House, który w połowie minionej dekady był prezentowany na kilku kanałach telewizyjnych w Kanadzie i USA, a także na specjalnych pokazach m.in. w Salwadorze oraz Izraelu․ W 2017 r. Castellanos został uhonorowany przez Instytut Yad Vashem tytułem Sprawiedliwego wśród Narodów Świata. To czwarty Sprawiedliwy pochodzący z Ameryki Łacińskiej. Tak zwanym certyfikatom salwadorskim oraz postaci Castellanosa i jego przyjaciela George'a Mantella poświęcono już kilka książek i filmów dokumentalnych, ale nadal wiele okoliczności i szczegółów dotyczących ich działalności pozostaje nieznane. W Polsce wiedza o nich jest nikła.
\end{abstract}

\section{Oficer wielkich talentów}

W przedwojennej Republice Salwadoru płk José Arturo Castellanos Contreras był uważany za oficera największych talentów. Castellanos to w tym kraju dość powszechne popularne nazwisko, ale jego rodzina miała bardzo dobrą pozycję społeczną i spore wpływy. Genealogicznie była związana z grupą „Czter-

${ }^{1}$ Pragnę podziękować moim szwedzkim przyjaciołom Gabrielowi i Victorowi Wróblewskim za materiały do tego artykułu nadesłane z Salwadoru. W Palmarcito, w salwadorskiej prowincji Libertal, Victor Wróblewski realizuje projekty edukacyjne w sierocińcu i ośrodku edukacyjno-wychowawczym dla młodzieży prowadzonym przez organizację charytatywną REMAR. Jest wnukiem płk. Michała Wróblewskiego, „Pana Miszy”, przedwojennego wychowawcy w warszawskim sierocińcu Janusza Korczaka na Krochmalnej. Zabiega o nadanie ośrodkowi w Palmarcito imienia płk. Castellanosa. 
nastu Rodzin”, nazywaną też „Kreolską Oligarchią”, wywodzącą swój rodowód albo bezpośrednio od hiszpańskich konkwistadorów, którzy dotarli na te ziemie w 1524 r., albo od lokalnej arystokracji ukształtowanej na początku XIX w. po utworzeniu Cesarstwa Meksyku. Przy czym liczba „czternaście” nie odnosi się do liczby rodów, lecz do liczby okręgów terytorialnych, gdzie rody te utrzymywały władzę lub wpływy.

Urodził się 23 grudnia $1893 \mathrm{r}$. w rodzinnej hacjendzie otoczonej rozległą plantacją kawy u stóp wulkanu pod miastem San Vincente, będącym siedzibą władz prowincji o tej samej nazwie. Rodzina José Artura miała tradycje wojskowe. Ojciec Abelino Castellanos był generałem utworzonej w latach 1911-1913 elitarnej Gwardii Narodowej. Matka Isabel Contreras de Castellanos - także pochodząca z wpływowej rodziny - zmarła, gdy miał zaledwie dwa lata. Jego wychowaniem zajęły się dwie siostry, z których zwłaszcza starsza, już zamężna, odegrała w tym procesie decydującą rolę, dbając o staranną i wszechstronną edukację brata.

„Ojciec został wychowany na dwa sposoby: twardy i miękki - mówiła po latach Frieda Castellanos de García, córka pułkownika, w wywiadzie dla dziennika „La Nacion”. - Dziadek ze strony ojca był bardzo surowy, konkretny. Miał wysokie poczucie odpowiedzialności i honoru. Moja ciocia była wyjątkowo mądra, ciepła i wrażliwa"2.

Kiedy w wieku siedemnastu lat José Arturo zdecydował - za przykładem ojca - wybrać ścieżkę kariery wojskowej i rozpoczął studia w Wojskowej Szkole Inżynieryjnej (Escuela Politécnica Militar) w stolicy kraju San Salwador, był jedynym jej słuchaczem, który oprócz hiszpańskiego znał jeszcze trzy języki: niemiecki, francuski i angielski, i uczył się czwartego - włoskiego.

Bezpośrednio po ukończeniu studiów w 1914 r. objął pierwsze samodzielne stanowisko oficerskie - co było sytuacją wyjątkową - jako dowódca baterii w pułku artyleryjskim. Jego kariera wojskowa przez kolejne lata była związana z artylerią. Okazał się bardzo uzdolnionym dowódcą i organizatorem, dość szybko awansował na kolejne stopnie oficerskie, zajmował też coraz wyższe stanowiska. W 1921 r. został przeniesiony - jak niegdyś jego ojciec - z wojska liniowego do Gwardii Narodowej, gdzie pełnił funkcję zastępcy dowódcy tej formacji ds. artylerii. W grudniu 1931 r. poparł pucz wojskowy gen. Maximiliana Hernándeza Martíneza, który po obaleniu demokratycznego rządu lidera Partii Pracy Artura Arauja i krwawym stłumieniu chłopskiej rebelii wprowadził dyktaturę i zapoczątkował wieloletni okres rządów autorytarnych, kontrolowanych przez wojsko oraz plantatorską oligarchię.

Generał Hernández z fascynacją spoglądał na europejski faszyzm, zwłaszcza włoski, a przede wszystkim podziwiał rosnącą potęgę Japonii i Trzeciej Rzeszy. $\mathrm{Z}$ roku na rok rosły niemieckie wpływy ekonomiczne w Salwadorze, a co za tym idzie - wpływy polityczne i militarne. Po 1936 r. przywódca salwadorskich nazi-

${ }^{2}$ „La Nacion”, 5 VI 2011, s. 5. 
stów i równocześnie niemiecki konsul baron Wilhelm von Hundelshausen objął prezesurę Banku Hipotecznego, kluczowej państwowej instytucji finansowej, a komendantem Akademii Wojskowej mianowano emerytowanego generała Wehrmachtu Eberhardta Bonstedta. W 1939 r. Hernández zorganizował w stolicy publiczne obchody urodzin Hitlera.

Salwador nawiązał też bliskie relacje z Włochami Mussoliniego, przede wszystkim w dziedzinie wojskowej. Reorganizację niewielkiego salwadorskiego lotnictwa wojskowego powierzono włoskiemu doradcy, a w 1938 r. poinformowano o zawarciu z włoską wytwórnią Caproni kontraktu na zakup kilkunastu samolotów bojowych. Jednym z efektów tego zbliżenia było wysłanie Castellanosa - awansowanego po puczu do Sztabu Generalnego Sił Zbrojnych Republiki Salwadoru - na kurs oficerów sztabowych w Akademii Wojskowej w Turynie. Był to kurs dla oficerów armii państw sojuszniczych, m.in. Portugalii i Rumunii. Castellanos ukończył go z wyróżnieniem i zaraz po powrocie do kraju w 1936 r. został awansowany do stopnia pułkownika oraz mianowany zastępcą szefa Sztabu Generalnego.

Wydaje się, że pobyt we Włoszech wzbudził u Castellanosa jeśli nie fascynację, to z pewnością zainteresowanie Europą. Bardzo szybko po objęciu nowego stanowiska przekonał Sztab Generalny, że armia wymaga nowego uzbrojenia. W czerwcu 1937 r. stanął na czele specjalnej misji wojskowej, która wyruszyła do Europy w celu nawiązania kontaktów z europejskimi firmami zbrojeniowymi. Swój rekonesans rozpoczęła od Czechosłowacji, która była wówczas jednym z czołowych producentów uzbrojenia, a jej nowoczesny przemysł zbrojeniowy nie dyktował wygórowanych - jak na tę branżę - cen. Misja odwiedziła też kilka innych krajów europejskich, nawiązując kontakty w sferach wojskowych i przemysłowych.

Utalentowany oficer Castellanos był w zasadzie już u samego szczytu wojskowej kariery. W krótkim czasie mógł się spodziewać awansu generalskiego i kolejnego wysokiego stanowiska w armii. Tymczasem sprawy potoczyły się inaczej. W ciągu kilku tygodni po powrocie z Europy Castellanos pożegnał się z kierowniczym stanowiskiem w Sztabie Generalnym, a następnie - po 26 latach służby wojskowej - został odesłany w stan spoczynku i przeniesiony do dyspozycji Ministerstwa Spraw Zagranicznych.

Córka pułkownika Frieda Castellanos de García i jego wnuk Boris Castellanos twierdzili potem, że popadł on w stan niełaski, ponieważ był przeciwny dyktatorskiej polityce Hernándeza. Dotychczasowa kariera pułkownika raczej o tym nie świadczyła, ale do jakiejś różnicy poglądów w Sztabie Generalnym być może na tle koncepcji modernizacyjnych armii - dojść musiało i pułkownik zapłacił za to dymisją. Były zastępca szefa Sztabu Generalnego, przechodząc do służby zagranicznej, mógł liczyć na stanowisko ambasadorskie. Tymczasem zaoferowano mu miejsce w korpusie konsularnym, a więc znacząco niższe rangą, prestiżem oraz o wiele mniej korzystne finansowo. Za to został wysłany do Europy, na czym zapewne mu zależało. Jeszcze w 1937 r. trafił do Wielkiej Brytanii 
na stanowisko konsula generalnego w Liverpoolu. Być może było tam akurat wakujące miejsce, a pułkownik nie chciał bezczynnie siedzieć w kraju? Niecały rok później przeniesiono go do Niemiec, uważanych przez Hernándeza za głównego sojusznika. Nie mogło zatem być mowy o skierowaniu do tego kraju kogoś, kto byłby jego politycznym przeciwnikiem.

W połowie $1938 \mathrm{r}$. Castellanos otrzymał niemieckie exequatur i objął stanowisko konsula w Hamburgu. Z hamburskiego biura obserwował exodus niemieckich Żydów, noc kryształową w listopadzie tego roku oraz wszystko, co nastąpiło potem. Było już po anszlusie, Trzecia Rzesza zajęła Czechosłowację, napadła na Polskę, wybuchła druga wojna światowa. Z pewnością w swoich raportach kierowanych do kraju opisywał te wydarzenia. Do konsulatu w Hamburgu zgłaszali się Żydzi mający krewnych w Salwadorze, w nadziei na uzyskanie wizy. 2 stycznia 1939 r. Castellanos wysłał raport do Miguela Ángela Arauja, ministra spraw zagranicznych Salwadoru, w którym przedstawił sytuację wewnętrzną w Rzeszy i poprosił o pozwolenie na wydawanie wiz Żydom, którzy chcieliby opuścić Niemcy. Wcześniej, w Liverpoolu, Castellanos wystawił pewną liczbę wiz żydowskim uciekinierom. W odpowiedzi został upomniany za wydane już wizy i otrzymał zdecydowany zakaz wydawania kolejnych. Mimo to konsulat hamburski wystawił wizy jeszcze kilku osobom³ ${ }^{3}$.

Rząd Hernándeza już od 1936 r. prowadził restrykcyjną politykę wobec Żydów. Miejscowej społeczności żydowskiej bardzo ograniczono możliwości sprowadzania krewnych z zagranicy. Wiele rodzin musiało swoich krewnych uciekających z Europy kierować do sąsiednich krajów - Brazylii, Ekwadoru, Gwatemali i Panamy. 30 lipca 1939 r. na redę portu San Carlos de la Unión zawinął niemiecki statek Portland. Na pokładzie było 50 żydowskich uchodźców z Niemiec mających salwadorskie wizy. Otrzymali je w Budapeszcie i Amsterdamie, płacąc tamtejszym konsulom po 500 USD. Władze Salwadoru uznały, że wizy zostały wydane nielegalnie, i nie zezwoliły ich posiadaczom zejść na ląd. Musieli wrócić do Niemiec. Salwador zamknął dla Żydów swoje granice.

W hamburskim konsulacie płk Castellanos spędził trzy lata. Jego misja w Trzeciej Rzeszy zakończyła się w połowie 1941 r. Szwajcarskie MSZ otrzymało z San Salwador listy komisyjne wyznaczające Castellanosa na konsula generalnego w Genewie i udzieliło mu exequatur. Nowy konsul generalny oficjalnie rozpoczął urzędowanie w genewskiej placówce 4 listopada $1941 \mathrm{r}^{4}$

3 https://www.warhistoryonline.com/history/jose-arturo-castellanos-contreras-latinoschindler.html (dostęp 11 IV 2019 r.).

${ }^{4}$ Cnel. José Arturo Castellanos: Héroe del Holocausto, San Salvador: Ministerio de Relaciones Exteriores de El Salvador, 2010, s. 9-12. Por. Cancilleria presenta segunda edicion del libro „Cnel. José Arturo Castellanos, Heroe del Holocausto”, Ministerio de Relaciones Exteriores de El Salvador, Press release, 18 VII 2011 r., w zbiorach autora. 


\section{Narodziny George'a Mantella}

György Mandl, określany zwykle jako węgierski Żyd, pochodził z miejscowości noszącej węgierską nazwę Szászlekence, leżącej w Transylwanii, czyli Siedmiogrodzie, o który toczył się ustawiczny spór węgiersko-rumuński i który w XX w. trzykrotnie przechodził z rąk do rąk $k^{5}$. Dzisiaj to miasteczko Lechinta w rumuńskim okręgu Bistrița-Năsăud (węg. Beszterce-Naszód), którego stolicą jest Bystrzyca. Urodził się 11 grudnia 1901 r. w ortodoksyjnej rodzinie żydowskiej ${ }^{6}$. Jego ojcem był dobrze sytuowany właściciel młyna, Baruch Jehuda Mandl, a matką Ida Mandl z domu Spitz. Jego dziadkiem ze strony ojca był znany i bardzo szanowany w tamtejszej społeczności żydowskiej rabin Icchok Jaakow Mandl. György miał trzy siostry i dwóch braci. Po pierwszej wojnie światowej, gdy Transylwania znalazła się w granicach Rumunii, rodzina Mandlów pozostała w tym kraju, natomiast György przeniósł się do Budapesztu. W 1928 r. ożenił się tam z tancerką Irene Berger, a w 1930 r. urodził im się jedyny syn Imre ${ }^{7}$.

Lata trzydzieste to okres sukcesów Mandla w interesach. W Rumunii założył dobrze prosperującą fabrykę tekstyliów. W 1933 r. wszedł w cichą spółkę z dwoma rumuńskimi partnerami, którzy zajmowali wysokie stanowiska w armii rumuńskiej, i dzięki nim z powodzeniem mógł się zająć pośrednictwem w handlu bronią, sprzętem oraz wyposażeniem wojskowym w krajach Europy Środkowo-Wschodniej i na Bałkanach. Prowadził też rozległe interesy finansowe w Niemczech i Austrii.

Po raz pierwszy zetknął się z płk. Castellanosem podczas pobytu salwadorskiej misji wojskowej w Europie w czerwcu 1937 r. Armia Salwadoru dokonała wówczas znaczących zamówień w Czechosłowacji i Rumunii na dostawy broni i sprzętu, a Mandl był zapewne jednym z pośredników spajających zawierane transakcje. Gdy pułkownik został skierowany do służby konsularnej w Europie, ich znajomość przybrała stały charakter, a Mandl zajął się pośrednictwem w imporcie kluczowego salwadorskiego produktu - ziarna kawowego. Zapewne plantacja rodziny Castellanosów dobrze na tym pośrednictwie wychodziła, a Castellanos i Mandl najwyraźniej nabrali do siebie pełnego zaufania. Więcej, zaprzyjaźnili się.

Nie bez znaczenia było to, że dla pułkownika gwarancję wiarygodności węgierskiego biznesmana stanowili jego dyskretni wspólnicy. Pułkownik, potem

\footnotetext{
${ }^{5}$ Rodzina używała nazwiska Mandl i w takiej wersji posługiwał się nim przez całe życie Josef, młodszy brat Györgyego. On sam zmienił je w latach dwudziestych na Mandel, a potem - wraz ze zmianą imienia - na Mantello. W raportach i doniesieniach szwajcarskiej policji figurował jako Mandel-Mantello. Po wojnie urzędowo przyjął takie podwójne nazwisko dla siebie i swoich dzieci.

${ }^{6}$ W niektórych biogramach podawany jest rok 1903; http://www.raoulwallenberg.net/ saviors/diplomats/list/george-mandel-mantello-485/.

${ }^{7}$ David Kranzler, The Man Who Stopped the Trains to Auschwitz: George Mantello, El Salvador, and Switzerland's finest hour, Syracuse, NY: Syracuse University Press, 2000, s. 13-15.
} 
generał Gheorghe Drăgănescu przez wiele lat zajmował ważne stanowiska w rumuńskiej armii. Między innymi w 1927 r. reprezentował swój kraj w polsko-rumuńskiej komisji granicznej, później był członkiem zespołu, który zdecydował o zakupie przez Rumunię licencji na produkcję polskiego samolotu myśliwskiego PZL P-24 ${ }^{8}$. Niewykluczone, że Castellanos poznał generała podczas wizyty w Bukareszcie w 1937 r. Drugiego rumuńskiego oficera, płk. Vasilescu, mógł poznać $\mathrm{w}$ Turynie podczas międzynarodowego kursu sztabowego.

W 1939 r., gdy Salwador zamykał swoje granice przed Żydami i zaostrzał politykę wizową swoich placówek wobec uciekinierów z Europy, konsul Castellanos wystawił Mandlowi paszport dyplomatyczny, mianując go konsulem honorowym Salwadoru w Czechosłowacji, Jugosławii i Rumunii z siedzibą w Bukareszcie. Sam paszport nie chronił wystarczająco jego posiadacza przed wymierzonymi w Żydów ograniczeniami prawnymi i represjami. Nazwisko Mandl było jak gwiazda Dawida wypalona na czole. Castellanos musiał notyfikować swoją decyzję o ustanowieniu nowego konsula honorowego nie tylko w swoim macierzystym MSZ. Nie mogło to też ujść uwadze pionu konsularnego berlińskiego Auswartiges Amt i nie wywołać zainteresowania Gestapo osobą nowego konsula. Mandl dokonał więc zmiany nazwiska.

Paszport dyplomatyczny podpisany przez Castellanosa został wystawiony na latynosko brzmiące nazwisko Mantello, węgierskie imię György zastąpiono zaś angielskim George'em. Dokument ten umożliwiał jego posiadaczowi, teraz George'owi Mantello, swobodę działania i podróżowania w państwach neutralnych i sprzymierzonych z Trzecią Rzeszą, a także zapewniał bezpieczeństwo jego żonie i synowi przebywającym w Budapeszcie. Zwykły paszport salwadorski otrzymał też młodszy brat Josef, który kilka lat wcześniej stał się jego wspólnikiem w interesach. Zapewne Mantello chciał zaopatrzyć w bezpieczne dokumenty również rodziców w Rumunii i resztę tamtejszej rodziny, ale to się nie udało.

We wrześniu 1940 r. sytuacja Żydów w Rumunii radykalnie się pogorszyła. Do władzy doszła faszystowska Żelazna Gwardia, proklamowano powstanie Narodowego Państwa Legionowego i „narodową rewolucję legionową", a 23 listopada Rumunia dołączyła do paktu trzech, stając się sojusznikiem państw osi. Z dniem 31 grudnia - na podstawie nowych przepisów rządowych - wszyscy Żydzi mieli być zwolnieni z pracy i skierowani do prac publicznych oraz obozów pracy. Nastąpiły konfiskaty nieruchomości żydowskich. Żelazna Gwardia zaczęła organizować pogromy Żydów. Do największego doszło w styczniu $1941 \mathrm{r}$. w Bukareszcie. Zamordowano 120 Żydów, setki zostało ciężko pobitych lub odniosło obrażenia. Zniszczono, splądrowano i zdemolowano tysiące sklepów, po-

${ }^{8}$ Polsko-rumuńska komisja graniczna, „Światowid. Ilustrowany Kurjer Cotygodniowy”, 23 IV 1927, s. 4. Biografie Gheorghe Drăgănescu, Agenției de Informații Geospațiale a Apărării „General de divizie Constantin Barozzi”; Otwarte niebo. Spotkanie panelowe, Polskie Zakłady Lotnicze, Baranów, 2 XII 1999 r., materiały konferencyjne w zbiorach autora. 
mieszczeń i domów żydowskich. Wcześniej - 30 sierpnia 1940 r. - w wyniku tzw. drugiego arbitrażu wiedeńskiego prowadzonego przez Niemcy i Włochy północna część Transylwanii z okręgiem Bistrița-Năsăud wróciła w granice Węgier. Rodziny Mandlów zamieszkałej w miasteczku Lechinta, któremu przywrócono nazwę Szászlekence, te dramatyczne wydarzenia więc nie dotknęły, ale Mantello $\mathrm{z}$ rosnącym niepokojem obserwował falę antyżydowskiej przemocy.

\section{Tysiąc chronometrów dla RAF}

Jesienią 1941 r. Mantello podjął decyzję o likwidacji swoich interesów w Rumunii i w pozostałych krajach Europy Środkowo-Wschodniej. Zamierzał schronić się wraz z rodziną w Szwajcarii. Razem z bratem sukcesywnie i ostrożnie przez wiele miesięcy transferowali swoje kapitały do tego kraju. Byli ludźmi zamożnymi i ich zasoby gwarantowały im niezależność finansową. Mantello nie zdołał zrealizować swoich zamiarów do końca. Na początku grudnia $1941 \mathrm{r}$., po japońskim ataku na Pearl Harbor, Stany Zjednoczone przystąpiły do wojny, a profaszystowska dotychczas Republika Salwadoru pod polityczną i ekonomiczną presją Waszyngtonu także wypowiedziała wojnę państwom osi. Konsula Mantella przestała chronić neutralność kraju, którego dokumentem dyplomatycznym się posługiwał. $\mathrm{Z}$ dnia na dzień stał się przedstawicielem wrogiego obozu i musiał opuścić Rumunię wraz z innymi dyplomatami neutralnych dotychczas państw, których zbiorowy wyjazd koleją do Szwajcarii zorganizowali i konwojowali przedstawiciele Międzynarodowego Czerwonego Krzyża.

Na granicy włosko-jugosłowiańskiej, którą kontrolowało wtedy faszystowskie Niezależne Państwo Chorwackie, został aresztowany przez mało rozgarniętych chorwackich żandarmów, być może podejrzewających, że za paszportem na nazwisko George Mantello ukrywa się Żyd Georges Mandel, ostatni minister spraw wewnętrznych Francji przed jej kapitulacją, poszukiwany przez reżim Vichy i Gestapo. Mantella odstawiono więc do biura Gestapo w Zagrzebiu. Choć pomyłka się wyjaśniła, a na polecenie Edmunda Veesenmayera zarządzającego w imieniu Trzeciej Rzeszy marionetkowym państwem poglavnika Ante Pavelicia traktowano go jako dyplomatę dość kurtuazyjnie, znalazł się w areszcie domowym, w hotelu, którego nie mógł opuszczać. Spędził tak ponad miesiąc, gdyż Veesenmayer i ustasze nie mogli się zdecydować, co z nim zrobić. Pomogli mu obaj rumuńscy wspólnicy, przede wszystkim płk Vasilescu, który do zajęcia Jugosławii przez Niemców był attaché wojskowym w Belgradzie.

Już po wojnie Mantello, człowiek rozmowny i towarzyski, chętnie opowiadał o tych wydarzeniach. Miał uciec z Zagrzebia rumuńskim samolotem wojskowym. Wykradł się z hotelu i wyposażony $\mathrm{w}$ fałszywe dokumenty rumuńskiego oficera wsiadł na pokład rumuńskiego samolotu wojskowego, udając drugiego pilota. Potem w Bukareszcie przez kilka tygodni usiłował zdobyć kolejne fałszywe dokumenty, które pozwoliłyby mu wyjechać pociągiem do Szwajcarii. Ostatecznie wjechał do Szwajcarii, posługując się paszportem i wizą swego przyjaciela Vasi- 
lescu. Niezależnie od tego, ile prawdy było w tych barwnych opowieściach, jest oczywiste, że ucieczka - najpierw z Zagrzebia, potem z Bukaresztu - nie należała do łatwych, musiała być pełna niebezpieczeństw i niecodziennych sytuacji ${ }^{9}$.

Ostatecznie w maju 1942 r. znalazł się w Genewie, wynajął apartament w eleganckim hotelu DeBerg i rozpoczął nowy etap życia. Jako człowiek bardzo zamożny - a jego szwajcarskie kapitały oceniano na kilkanaście milionów franków szwajcarskich - mógł skupić się na swoich prywatnych sprawach. Ale Mantello nie miał takiego pomysłu na życie. Zameldował Castellanosowi swoje przybycie, a ten włączył go w skład personelu placówki jako urzędnika konsularnego. To była ochrona przed nadmierną inwigilacją ze strony szwajcarskiej policji, która żydowskich uciekinierów traktowała z najwyższą niechęcią i potrafiła dotkliwie uprzykrzać im pobyt.

Konsul Castellanos należał do korpusu dyplomatów cywilnych, ale szanowano go i ceniono w kręgu dyplomatów wojskowych rezydujących w Szwajcarii. Pułkownik utrzymywał bliskie relacje $\mathrm{z}$ attachés wojskowymi Włoch, Portugalii, Turcji, Wielkiej Brytanii i Szwecji. Łączył ich esprit de corps dyplomowanych oficerów sztabowych, to zaś sprzyjało świadczeniu wzajemnych poufnych przysług w realizacji zadań, jakie musieli wykonywać na rzecz swoich państw, zwłaszcza tych, które mogły mieć charakter nielegalny. Castellanos, znakomicie obracający się w tym środowisku, i Mantello, jeszcze lepiej obracający się w sferach biznesowo-finansowych, stworzyli w Szwajcarii całkiem rozległą sieć kontaktów dyplomatycznych, finansowych, handlowych i towarzyskich. Dla wzmocnienia prestiżu i formalnej pozycji swojego partnera 25 sierpnia 1942 r. Castellanos mianował go pierwszym sekretarzem konsulatu, chociaż w strukturze etatowej salwadorskich placówek konsularnych takie stanowisko nigdy nie istniało.

W latach wojny neutralna Szwajcaria była szpiegowskim rajem i krzyżowały się tam interesy wszystkich służb specjalnych świata. Castellanos i Mantello nie unikali kontaktów ze światem wywiadów i działań niemieszczących się w granicach obowiązków konsularnych przewidzianych w prawie międzynarodowym. Jedną z pierwszych, a równocześnie najtrudniejszych tajnych operacji przeprowadzili, gdy o przysługę poprosił ich brytyjski attaché lotniczy komandor Ferdinand „Freddy” West. Anglik, weteran walk lotniczych podczas Wielkiej Wojny, w których stracił nogę i zdobył Krzyż Wiktorii, najwyższy brytyjski order wojenny, był bardzo poważany w kręgu dyplomatów wojskowych. Nikt tego nie anonsował ani nikt o to nie pytał, ale było wiadomo, że jest też wysoko postawionym oficerem brytyjskiego Secret Service.

West potrzebował precyzyjnych chronometrów produkowanych w Szwajcarii i objętych embargiem wojennym. Dokładniej - brytyjski RAF potrzebował tysiąca takich chronometrów do swoich samolotów myśliwskich. Mantello zakupił je bezpośrednio u producenta, płacąc dla bezpieczeństwa własną gotówką, a Castellanos przygotował dokumenty legalizujące transakcję i zorganizował

\footnotetext{
${ }^{9}$ https://math.dartmouth.edu/ lamperti/Holocaust_Heroes.pdf (dostęp 11 IV 2019 r.).
} 
przerzut chronometrów w poczcie dyplomatycznej do Lizbony, dalej na Bermudy, stamtąd zaś do Stanów Zjednoczonych, gdzie mogły już zostać przejęte przez Brytyjczyków. Komandor West zwrócił wszystkie poniesione koszty operacji, a wykonawcy nie doliczyli sobie nawet franka prowizji ${ }^{10}$.

Ta operacja - jedna z kilku co najmniej, jakie team Castellanos-Mantello mieli jeszcze przeprowadzić - spowodowała, że rezydentury wywiadów alianckich, zwłaszcza Secret Service oraz szwajcarskie biuro amerykańskiego wywiadu Office of Strategic Services (OSS) kierowane przez Allena Dullesa uważały ich za postaci poważne, wiarygodne i dochowujące dyskrecji. Ten czynnik wiarygodności i zaufania odegrał później niezwykle istotną rolę. W pewnym stopniu stanowił też ochronę przed ingerencją policji i władz szwajcarskich, które musiały dostrzegać, że dyplomaci niewielkiego i nic nieznaczącego Salwadoru cieszą się przyjaźnią i wsparciem przedstawicieli czołowych krajów alianckich, a także dyplomatów ważnych krajów neutralnych, takich jak Hiszpania, Portugalia i Turcja ${ }^{11}$.

\section{Konferencja u sędziego Guerrera}

Dla Mantella pierwszoplanowe pozostawały jednak sprawy żydowskie i w tym zakresie ściśle współpracował z bratem Josefem, który do Genewy dotarł kilka miesięcy przed nim. Przez poprzednie lata bracia wspierali finansowo żydowskie społeczności w Rumunii i na Węgrzech. Teraz włączyli się w działalność szwajcarskich organizacji żydowskich. Josef wszedł w skład komitetu szwajcarsko-węgierskiego (SHC), skupiającego żydowskich oraz nieżydowskich emigrantów węgierskich i organizującego akcje pomocowe dla kraju. Działał też w podobnym komitecie szwajcarsko-rumuńskim.

Przede wszystkim zaś obaj pozostawali w bliskich kontaktach z Agudat Israel - organizacją polityczną ortodoksyjnych Żydów o zasięgu światowym - i jej wpływowymi liderami Icchakiem Sterbuchem i Chaimem Eissem oraz członkami komitetu rabinów szwajcarskich: dr. Tuvią Lewensteinem, byłym naczelnym rabinem Holandii, Arminem Kornfeinem, rabinem z Zurychu, i dr. Zvim Taubesem, kierującym komitetem rabinów. Współpracowali też z Abrahamem Silberscheinem, kierującym genewskim Komitetem Pomocy Żydom Dotkniętym przez Wojnę (RELICO).

Mantello przyjechał do Genewy z pomysłem stworzenia mechanizmu finansowego, który pozwoliłby ocalić kapitały i majątki żydowskie w krajach okupowanych. Usiłował zainteresować tym pomysłem organizacje żydowskie, ale ich liderzy - skłóceni i niechętni - do stołu usiąść nie chcieli. Nie zamierzał pozostawać bezczynny i szukał innych sposobów na zorganizowanie pomocy dla

${ }^{10}$ Kranzler, The Man Who Stopped the Trains to Auschwitz..., s. 8-9, 260.

${ }^{11}$ Pat Reid, Winged Diplomat: The Life Story of Air Commodore „Freddy”, London: Chatto and Windus, 1962, s. 87-91. 
potrzebujących jej współbraci. Między innymi skupił wokół siebie spore grono studiującej w Genewie młodzieży węgierskiej pochodzenia żydowskiego i nieżydowskiego, finansując ich klub, a równocześnie angażując ich w rozmaite otwarte i dyskrecjonalne akcje pomocowe dla kraju.

W połowie 1942 r. Mantello dowiedział się od Chaima Eissa o akcji pozyskiwania dla Żydów w okupowanych krajach paszportów państw neutralnych. Eiss, jeden z założycieli Agudy, utrzymywał kontakty z gettami w Polsce i innych okupowanych krajach oraz z biurami tej organizacji w Nowym Jorku, Londynie i Stambule. Z krajów pod okupacją docierały do Szwajcarii zdjęcia i dane personalne Żydów, tam produkowano paszporty, pozostawiając je na miejscu, a ich kopie wysyłano z powrotem. Niemcy nawet po przystąpieniu tych państw do wojny honorowali te paszporty, a Żydzi dysponujący takimi dokumentami jako obcokrajowcy byli inaczej traktowani niż reszta współbraci, Heinrich Himmler miał bowiem plan ich wymiany na obywateli niemieckich internowanych po stronie aliantów ${ }^{12}$.

Mantello, poproszony o pomoc finansową przy zakupie paszportów Paragwaju, które dostarczał konsul honorowy, berneński adwokat Huegly, był zbulwersowany tym, że organizacje żydowskie muszą ponosić takie wysokie koszty za latynoamerykańskie dokumenty, co podkreślał w swoich wyjaśnieniach składanych tuż po wojnie na ręce Georges'a Brunschviga ${ }^{13}$. Korzystając zatem z możliwości, jakie dawała praca w konsulacie, bez żadnej opłaty wystawił na własną rękę - nie informując o tym Castellanosa - kilka dokumentów paszportowych, które za pośrednictwem Eissa zostały wysłane do Warszawy, a także do Holandii, Belgii, Francji i na Słowację.

Gdy jesienią 1942 r. Eiss i Sterbuch poprosili Mantella o więcej dokumentów, obiecał pomoc, ale wiedział, że bez akceptacji Castellanosa nie będzie mógł tej obietnicy zrealizować. Otwarcie przedstawił mu sytuację, potrzeby Agudy i możliwość podjęcia tajnej akcji humanitarnej, która mogła ocalić życie setkom ludzi. Mantello wiedział, że niektórzy konsulowie honorowi sprzedają organizacjom żydowskim dokumenty, traktując ten proceder przede wszystkim jako dodatkowe źródło dochodu. Zresztą przez cały XX w. konsulowie honorowi, nieodpowiadający w praktyce przed władzami reprezentowanego przez siebie kraju, byli dostawcami rozmaitych fałszywych lub nielegalnych dokumentów dla wszelkiego rodzaju „ludzi podziemnych” - uchodźców politycznych, szpiegów,

${ }^{12}$ Przepisy dotyczące internowania Żydów cudzoziemców wydano w czerwcu $1942 \mathrm{r}$. i uściślono w rozporządzeniu RSHA z lutego 1943 r. Według niego wszyscy Żydzi, którzy oprócz innego obywatelstwa mogą otrzymać także prawo do paszportu angielskiego czy amerykańskiego, podlegają internowaniu. W dokumencie tym jest mowa o planowanej wymianie i „zainteresowaniu organizacji żydowskich, tak że możliwe jest korzystne wykorzystanie Żydów”. Dziękuję Agnieszce Hasce za przytoczone uzupełnienie.

${ }^{13}$ Georges Brunschvig, wybitny prawnik i wieloletni prezes Szwajcarskiej Federacji Społeczności Żydowskich (SIG), prowadził po wojnie postępowanie mające wyjaśnić motywy i okoliczności działań Mantella (Kranzler, The Man Who Stopped the Trains to Auschwitz..., s. 266). 
zbiegów kryminalnych, aferzystów i osób wykluczonych. Zwykle robili to za jakąś opłatą. I nie była to wiedza tajemna ${ }^{14}$.

Ani Castellanos, ani Mantello nie zamierzali tak postępować. Akcja miała mieć charakter wyłącznie humanitarny, ratunkowy, bez jakiegokolwiek aspektu merkantylnego. Nie obciążałaby też budżetu konsulatu, ponieważ Mantello gotów był pokryć wszystkie niezbędne koszty z własnych prywatnych funduszy. Pułkownik, znający niezmienne, nieprzejednanie negatywne stanowisko swojego rządu w sprawie przyjmowania żydowskich uchodźców, nie łudził się, że może uzyskać akceptację swojego MSZ dla takiej akcji. Można sądzić, że dyskretne operacje finansowo-handlowe prowadzone przez Mantella obu im zapewniały stabilizację finansową i poczucie sporej niezależności, a może nawet dawały jakąś gwarancję dobrego bytu po wojnie. Mimo to Salwadorczyk był w całkowicie innej sytuacji niż konsulowie honorowi. Im w razie wpadki groziło jedynie cofnięcie exequatur, jemu - wydalenie ze Szwajcarii, a potem proces przed salwadorskim sądem. Na wyrozumiałość gen. Hernándeza nie miał co liczyć, a jako oficer za zdradę dyplomatyczną mógł zostać rozstrzelany. Nawet gdyby ocalił głowę, straciłby swoje życiowe zaplecze, państwowe uposażenie, rządową emeryturę i prywatny majątek ${ }^{15}$.

Dobiegający pięćdziesiątki, owdowiały, Castellanos akurat się zakochał w młodej Szwajcarce i zaczął myśleć o poważnym ułożeniu sobie z nią życia po wojnie, był więc pełen obaw życiowych. Wahał się. Może się po ludzku bał? Wiele lat po wojnie jego córki uważały, że to właśnie ich matka Maria Schurmann, pochodząca z rodziny o żydowskich korzeniach, miała wpływ na to, że pułkownik pokonał swoje wątpliwości ${ }^{16}$.

Aby złamać rządowe rozkazy i odrzucić zasadę urzędniczej lojalności, pułkownik potrzebował czegoś więcej niż wsparcia kochającej kobiety. Być może

${ }^{14}$ Tamara Łempicka, malarka, uciekając z bolszewickiej Rosji, za fałszywy paszport zapłaciła honorowemu konsulowi Syjamu własnym ciałem. Warto przypomnieć casus Juliana Tuwima i Antoniego Słonimskiego, którzy z pomocą Adolfa Kohna, konsula honorowego Haiti, sami spreparowali sobie wizy „Przedstawicielstwa Republiki Haiti w Rzymie”, dzięki czemu w 1940 r. przedostali się do Portugalii, a stamtąd - nie bez trudności - do Brazylii. Kohna wspominała też Maria von Bibikoff, żona czeskiego aktora Hugona Haasa: „ocalił nas oboje i wielu swoich ziomków, wydając wszystkim wizy".

${ }^{15}$ Castellanos znał zapewne los portugalskiego konsula w Bordeaux Aristidesa de Sousy Mendesa, który wbrew swemu rządowi wydał Żydom setki wiz, za co jesienią 1940 r. odwołano go do kraju, usunięto ze służby dyplomatycznej i pozbawiono prawa do emerytury. W międzynarodowych kręgach dyplomatycznych było to wydarzenie głośne z powodu towarzyszącego mu skandalu obyczajowego: de Sousa Mendes, gorliwy katolik, przykładny mąż i ojciec czternaściorga dzieci, wdał się w romans z piosenkarką Andrée Cibial, która ogłosiła publicznie podczas niedzielnej mszy, że jest z nim w ciąży, a następnie zjawiła się w konsulacie, żądając, by de Sousa porzucił żonę i uznał mające się narodzić dziecko.

${ }^{16}$ Un Salvadoreño en la historia del pueblo judío, „Long Island Al Día”, 10 IX 2010; https:// www.aciprensa.com/noticias/la-historia-del-catolico-de-el-salvador-que-salvo-40-mil-judios-del-holocausto-78277 (dostęp 11 IV 2019 r.). 
potrzebował mandatu prawnego i politycznego. Zwrócił się do José Gustava Guerrera, prezesa Stałego Trybunału Sprawiedliwości Międzynarodowej. Siedzibą trybunału, pierwszego sądu międzynarodowego o zasięgu powszechnym, powołanego przez Ligę Narodów w 1921 r., była Haga, ale po zajęciu Holandii przez Niemców przeniósł się on do Genewy.

Sędzia Guerrero był wybitnym prawnikiem o ogromnym autorytecie międzynarodowym. Był też rodakiem Castellanosa. Ponad dziesięć lat spędził w Rzymie jako ambasador Salwadoru przy Kwirynale i przy Watykanie, a przed puczem gen. Hernándeza piastował tekę ministra spraw zagranicznych, był też krótko prezydentem kraju i reprezentował go w Lidze Narodów. W Salwadorze cieszył się wielkim szacunkiem, a dla sił przeciwnych dyktaturze był moralnym i politycznym autorytetem.

Konferencja u sędziego Guerrera, na którą Castellanos zabrał Mantella, przesądziła o jego decyzji. Prezes trybunału międzynarodowego był dogłębnie poruszony informacjami o sytuacji Żydów w Polsce, na Węgrzech, w Słowacji, Czechach i Rumunii. Sędzia nienawidził wojen i był radykalnym pacyfistą. Pomysł wydawania dokumentów mogących ratować życie musiał uznać za całkowicie uprawniony w nieludzkich warunkach wojennych, jakie stworzyli Niemcy. Było oczywiste, że humanitarne i ratunkowe cele tej akcji stawiają ją ponad rozkazami dyktatorskiego rządu o wątpliwym mandacie.

Guerrero odradził natomiast wydawanie paszportów. Paszport - ewidencjonowany dokument podróży rodzący po stronie Salwadoru zobowiązanie prawne do przyjęcia jego posiadacza - mógł być stosunkowo łatwy do weryfikacji przez Niemców bądź władze salwadorskie. Łatwiejszy w przygotowaniu, a znacznie trudniejszy do zweryfikowania mógł być dokument poświadczający obywatelstwo. Skontrolowanie ewidencji takich certyfikatów obywatelstwa stwarzałoby problemy zarówno dla Niemców, jak i władz Salwadoru, zwłaszcza gdyby dokumenty były antydatowane, co rekomendowa ${ }^{17}$.

Castellanos dostrzegł zielone światło, jakie zapalił przed nim sędzia Guerrero. Mantello dostał od swego szefa wolną rękę w kwestii wystawiania Żydom ratunkowych certyfikatów poświadczających obywatelstwo Salwadoru. Akcja ruszyła.

\section{Pułkownik Castellanos i akcja Poselstwa RP w Bernie}

Zapotrzebowanie na paszporty, z którym Eiss zwrócił się do Mantella, miało związek z sytuacją w Polsce, gdyż los ludności żydowskiej na terenie Generalnego Gubernatorstwa stawał się coraz bardziej dramatyczny. Paszporty południowoamerykańskie mogły jeszcze jakąś liczbę Żydów ocalić. Kupowano je więc od

${ }^{17}$ José Miguel Arévalo-Rengifo, La vida de Dr. José Gustavo Guerrero 1876-1958. El salvadoreño que trascendió las fronteras, San Salvador: Imprenta Jaime, 2010, s. 28-29; Jose Zometa, La historia ha consagrado al Dr. Guerrero como inmortal, „El Diario de Hoy”, 16 X 2018. 
rezydujących w Szwajcarii konsulów honorowych Paragwaju, Hondurasu, Kostaryki, Gwatemali, Haiti, Peru, Boliwii, Ekwadoru, Nikaragui, Panamy, Urugwaju i Wenezueli, a w tej akcji ważną rolę odegrała polska placówka dyplomatyczna - Poselstwo RP w Bernie kierowane przez Aleksandra Ładosia.

„Informacje o tzw. Grupie Berneńskiej, która w latach 40. wystawiała paszporty latynoamerykańskie Żydom z gett w okupowanej Polsce, po raz pierwszy pojawiły się dopiero w 2017 roku" - pisze Norbert Nowotnik w oficjalnym biuletynie Urzędu do Spraw Kombatantów i Osób Represjonowanych ${ }^{18}$. To dość bezwstydne kłamstwo. Wokół sprawy pozyskiwania paszportów latynoamerykańskich przez tzw. Grupę Berneńską, nazywaną też Grupą Ładosia, polityka historyczna "dobrej zmiany” buduje mitologię całkowicie nowego odkrycia historycznego, którego twarzą są dzisiaj polski ambasador w Bernie dr Jakub Kumoch oraz Michał Potocki i Zbigniew Parafianowicz, dziennikarze „Dziennika Gazeta Prawna"19. Mam za sobą wieloletnie doświadczenie dziennikarskie i wiem, że $\mathrm{w}$ tej profesji odkrywanie tajemnic dawno już odkrytych to rzecz zwyczajna.

Jedenaście lat wcześniej, w 2006 r., kupowanie południowoamerykańskich paszportów oraz udział $\mathrm{w}$ tej akcji berneńskiego poselstwa RP kierowanego przez ambasadora Ładosia opisała Agnieszka Haska w książce „Jestem Żydem, chcę wejść". Hotel Polski w Warszawie 1943, powołując się na artykuł Nathana Ecka w „Yad Vashem Studies”. Jako pierwsza też opracowała i opublikowała zarys biografii Ładosia ${ }^{20}$. Niewątpliwie dokumenty odtajnione niedawno z mocy prawa przez Archiwum Federalne w Bernie pozwoliły znacząco poszerzyć wiedzę o udziale i roli polskich dyplomatów w działaniach, które nazywa się teraz akcją paszportową, ale trudno uznać to za epokowe odkrycie zmieniające radykalnie obraz tamtych wydarzeń historycznych. Dzisiaj między dr Haską a ambasadorem Kumochem toczy się interesujący spór, w którym spokojna i rzeczowa ocena m.in. skuteczności berneńskiej akcji ratunkowej wobec polskich Żydów zderza się z wańkowiczowskim „chciejstwem”, by z tych samych faktów odlać spiżowy monument ${ }^{21}$.

Tematem zdecydowanej polemiki musi być też kwestia, jak działalność poselstwa miała się do akcji Castellanosa i Mantella. Ambasador Kumoch, występując w lutym 2018 r. na konferencji w Muzeum Pamięci Shoah w Paryżu, zaprezentował Grupę Berneńską jako „konspirację polsko-żydowską” i jednym tchem

\footnotetext{
${ }^{18}$ Norbert Nowotnik, Paszporty Paragwaju, czyli działalność Grupy Berneńskiej, „Kombatant" 2019, nr 3, s. 19.

${ }^{19}$ Michał Potocki, Zbigniew Parafianowicz, Polak na polecenie rządu ratował Żydów od Holokaustu. Świat się o tym nie dowiedział, „Dziennik Gazeta Prawna”, 7 VIII 2017.

${ }^{20}$ Agnieszka Haska, „Proszę Pana Ministra o energiczna interwencję”. Aleksander Ładoś (1891-1963) i ratowanie Żydów przez Poselstwo RP w Bernie, „Zagłada Żydów. Studia i Materiały" 2015, nr 11.

${ }^{21}$ Wywiad Pawła Smoleńskiego z dr Agnieszką Haską, „Gazeta Wyborcza”, 17 XII 2018, dodatek „Ale Historia”, nr 49; Jakub Kumoch, Państwo polskie ratowało Żydów. Polemika z dr Agnieszkq Haskq, „Gazeta Wyborcza”, 7 I 2019, dodatek „Ale Historia”, nr 1.
} 
wyliczył nazwiska jej uczestników: Silberschein, Ładoś, Eck, Rokicki, Kühl, Ryniewicz, oraz nazwiska współpracowników: „Castellanos, Mandel-Mantello, arcybiskup Bernardini (nie zapominajmy, że choć sam paszportów nie produkował, to akcję wspierał), Barreto, a także konsulowie, którzy paszporty sprzedawali". Polskie poselstwo miało stanowić jądro procesu produkcji paszportów, a konsulowie latynoamerykańscy „w tym schemacie byli głównie dostarczycielami towaru - paszportów, które sprzedawali dla zysku bądź w nielicznych, nie więcej niż dwu przypadkach, z powodów humanitarnych. W tej grupie byli m.in. konsul Castellanos i jego żydowski podwładny Mandel-Mantello, którzy - podobnie jak Kühl i jego polscy koledzy - nie brali pieniędzy"22.

Budowniczowie nowego mitu Grupy Berneńskiej czy Grupy Ładosia mają kłopot ze znalezieniem w nim miejsca dla Castellanosa i Mantella.

„Znaczną autonomię wobec polskiego poselstwa miały działania Konsula Generalnego Salwadoru Arturo Castellanosa" - mówił w rozmowie z portalem PolskieRadio.pl ambasador Kumoch. - Tutaj nie jestem w stanie odtworzyć sposobu działania. Najprawdopodobniej Poselstwo miało wyłącznie wgląd do list, bo $w$ jednej z depesz do Londynu informuje, ile stworzono paszportów Salwadoru"23.

„Prawdopodobnie Polacy kontrolowali również produkcję paszportów innych krajów Ameryki Łacińskiej (m.in. Hondurasu), jednak ich bezpośrednią produkcją zajmowali się konsulowie. Większość z nich robiła to dla pieniędzy czytamy z kolei w komentarzu zamieszczonym w portalu wPolityce.pl. - Wyjątkiem był m.in. Arturo Castellanos z Salwadoru, który rozdawał paszporty za darmo z przyczyn humanitarnych. Był on też stosunkowo najbardziej samodzielny w swoich działaniach"24.

Tak użyte określenia „znaczna autonomia” i „stosunkowo najbardziej samodzielny w swoich działaniach" w zamyśle autorów tych wypowiedzi miałyby chyba oznaczać, że owa „autonomia” i „samodzielność” pozostawały jednak związane z jakąś zależnością lub podporządkowaniem polskiemu poselstwu w Bernie jako głównemu organizatorowi akcji paszportowej.

W niczym nie umniejszając zasług posła Ładosia i podległych mu polskich urzędników konsularnych, trzeba zwrócić uwagę na to, co wynika z depeszy berneńskiego poselstwa RP z 25 lipca 1944 r., zawierającej zestawienie wszystkich paszportów uzyskanych przez polską placówkę. Z podanej przybliżonej liczby 4 tys. pozyskanych paszportów około 3 tys., czyli aż trzy czwarte, pochodziło

${ }^{22}$ Grupa Berneńska - dyplomaci Rzeczypospolitej Polskiej z pomocą Żydom. Wystapienie ambasadora RP w Szwajcarii dr. Jakuba Kumocha, wygłoszone 4 lutego 2018 r. w Muzeum Pamięci Shoah w Paryżu, „Polski Przegląd Dyplomatyczny” 2018, nr 2, s. 169-170.

${ }^{23}$ https://www.polskieradio.pl/5/3/Artykul/2025372,Ambasador-Polski-w-SzwajcariiPolacy-pomagali-przy-wykupie-Zydow-z-rak-nazistow-Alianci-byli-temu-przeciwni (dostęp 11 IV 2019 r.).

${ }^{24}$ https://wpolityce.pl/historia/377271-zapomniana-karta-z-dziejow-polskiej-pomocyzydom-falszywe-paszporty-ratowaly-zycie-setkom-ludzi (dostęp 11 IV 2019 r.). 
właśnie z konsulatu Salwadoru ${ }^{25}$. To zdaje się dowodzić, że to placówka salwadorska wniosła największy wkład $\mathrm{w}$ akcję paszportową ukierunkowaną na pomoc dla Żydów w Polsce.

W polskim piśmiennictwie postrzega się akcję czy też - po nowemu - „operację paszportową" Grupy Berneńskiej lub Grupy Ładosia jako całkowicie autonomiczną. Ambasador Kumoch w paryskim wystąpieniu zamknął ją w klamrze czasowej 1941-1943, przypominając przy okazji, że telegram rządu londyńskiego akceptujący tajne i nielegalne działania Ładosia „dotarł do niego dopiero w grudniu 1943 r., gdy akcja paszportowa była już zakończona”. Podobne przekonanie wynika również z podsumowania berneńskiej akcji dokonanego przez dr Haskę. „Doliczając promesy, można przyjąć, że w sumie w Szwajcarii wydano nie więcej niż 5000-5500 dokumentów, z czego zapewne większość, czyli owe 4000 trafiło do okupowanej Polski, w tym najwięcej do Warszawy"26.

Otóż trzeba jasno powiedzieć, że działania salwadorskiego konsulatu generalnego $\mathrm{w}$ żadnym stopniu nie były podporządkowane jakimkolwiek polskim czynnikom ani od nich zależne. Partnerami Castellanosa i Mantella nie byli poseł Ładoś ani Poselstwo RP w Bernie, lecz organizacje żydowskie. Wbrew przytoczonym opiniom prowadzona ze Szwajcarii akcja paszportowa ratująca Żydów nie zakończyła się w połowie $1943 \mathrm{r}$. Przeciwnie, w drugiej połowie tego roku i z początkiem 1944 r. nabrała rozmachu, a jej głównym centrum była tajna komórka zorganizowana pod egidą Castellanosa i Mantella.

Przyjmuje się dość ostrożnie, że powstało w jej ramach około 13 tys. salwadorskich certyfikatów obywatelstwa, co w zestawieniu z podaną w lipcowej depeszy Poselstwa RP liczbą 400-500 pozyskanych dokumentów honduraskich, 200-250 paragwajskich, około 100 peruwiańskich oraz od kilku do kilkunastu haitańskich, kostarykańskich, wenezuelskich, ekwadorskich i nikaraguańskich pokazuje wagę całkowicie humanitarnej akcji prowadzonej przez „stosunkowo najbardziej samodzielnego w swoich działaniach" konsula Castellanosa i jego „żydowskiego podwładnego”.

Co zaś najistotniejsze, poziom skuteczności tej akcji, zwłaszcza na Węgrzech, w porównaniu z rezultatami uzyskanymi w wyniku „polskiej akcji” okazał się znacząco wysoki. Wydaje się, że to powinno stać się przedmiotem osobnego studium lub choćby pogłębionej refleksji badawczej.

\section{Biuro Matthieux'a Mullera}

Początkowo Mantello sporządzał certyfikaty osobiście w konsulacie, ale gdy okazało się, że organizacje żydowskie potrzebują nie kilkunastu czy kilkudziesięciu, lecz znacznie więcej egzemplarzy, sprawa stawała się terminowo

\footnotetext{
${ }^{25}$ Agnieszka Haska, „Jestem Żydem, chcę wejść”. Hotel Polski w Warszawie 1943, Warszawa: Centrum Badań nad Zagładą Żydów i Wydawnictwo IFiS PAN, 2006, s. 53.

${ }^{26}$ Ibidem, s. 54.
} 
i technicznie coraz trudniejsza. W połowie 1943 r. Chaim Eiss, z którym Mantello był już zaprzyjaźniony, przedstawił mu i zarekomendował jako zaufanego pomocnika adwokata Matthieux’a Mullera, zbiegłego z Francji, gdzie wcześniej przewodził tamtejszej Agudzie. Ze względów bezpieczeństwa Mantello wynajął osobny lokal na konspiracyjne biuro dla Mullera, a po śmierci Eissa w listopadzie 1943 r. zatrudnił go w konsulacie salwadorskim na stałe. Muller szybko zorganizował niewielką grupę zaufanych żydowskich wolontariuszy spośród studentów z klubu wspieranego przez Mantella i z ich pomocą przejął część obowiązków związanych z wykonywaniem i dystrybucją certyfikatów dla osób, których fotografie i dane personalne dostarczali ludzie Agudy oraz Josef Mandl $\mathrm{z}$ ramienia $\mathrm{SHC}^{27}$.

Certyfikaty wypisywano maszynowo lub częściowo ręcznie na jednostronicowym formularzu, który pozostawał $\mathrm{w}$ archiwum biura, a jego uwierzytelnioną kopię wysyłano do odbiorcy. Stopniowo Mantello udoskonalał ich formę. Początkowo certyfikat był wystawiany w języku hiszpańskim lub francuskim, natomiast do kopii przeznaczonej do wysłania dołączano uwierzytelnione tłumaczenie na język niemiecki lub węgierski. Sporządzano też tłumaczenia na język holenderski, słowacki i rumuński. To była czasochłonna praca. Oprócz Mantella zwykłą obsadę biura stanowili Muller i pięciu studentów, ale w czasie kryzysu węgierskiego po wkroczeniu Niemców w 1944 r. zespół wzrósł do dwunastu osób. Certyfikaty podpisywał Mantello, a za ich wystawienie nie pobierano opłat.

Od połowy 1943 r. głównym kierunkiem wysyłki certyfikatów stały się Węgry, a także Słowacja i Rumunia. Dokumenty były imienne, wysyłano je z reguły pocztą, co organizował komitet szwajcarsko-węgierski, ale miał on też własnych zaufanych kurierów. Castellanos i Mantello mogli również w pewnej mierze korzystać z pomocy zaprzyjaźnionych dyplomatów portugalskich, rumuńskich i tureckich, wdzięcznych za rozmaite przysługi związane ze światem służb specjalnych.

W grudniu 1943 r. Mantello podjął próbę sprowadzenia do Szwajcarii żony i syna. Irene nie chciała opuścić Budapesztu, ponieważ opiekowała się dwojgiem zniedołężniałych rodziców, którzy bez niej nie daliby sobie rady. Do Szwajcarii miał więc przenieść się tylko trzynastoletni wówczas Imre, któremu zmieniono imię na Enrico. 0 zgodę na jego przyjazd Mantello zwrócił się do Heinricha Rothmunda, szefa Eidgenössischen Fremdenpolizei, szwajcarskiej policji ds. cudzoziemców, ten jednak kategorycznie odmówił i zapowiedział, że chłopiec zostanie zatrzymany na granicy, po czym będzie deportowany do Budapesztu.

Mantello ani myślał zrezygnować. Z pomocą komandora Westa i portugalskiego delegata w Międzynarodowym Czerwonym Krzyżu Narcisa Freire de Andradego chłopiec został wywieziony z Budapesztu. Przez Austrię i Włochy dotarł na stację kolejową na granicy włosko-szwajcarskiej, gdzie czekał na niego ojciec z przygotowanym paszportem dyplomatycznym. To trudne i niebezpiecz-

${ }^{27}$ Kranzler, The Man Who Stopped the Trains to Auschwitz..., s. 28-31. 
ne przedsięwzięcie doprowadziło do ostrego konfliktu Mantella ze szwajcarską policją, która już wcześniej interesowała się jego zróżnicowaną aktywnością. Castellanos musiał tłumaczyć się przed szwajcarskim MSZ.

Wiosną 1944 r. - podczas kryzysu węgierskiego - Rothmund usiłował aresztować Mantella, ale Castellanos za każdym razem zdecydowanie i konsekwentnie go bronił, dzięki czemu do końca wojny Mantello zachował dużą swobodę działania ${ }^{28}$.

W marcu 1944 r. z Węgier zaczęły nadchodzić coraz gorsze wiadomości. Do 1944 r. Żydzi węgierscy przetrwali we względnym spokoju. 19 marca spokój się skończył. Do kraju wkroczył Wehrmacht, na żądanie Berlina admirał Miklós Horthy utworzył proniemiecki gabinet pod kierownictwem Döme Sztójaya, który włączył się w przygotowanie i przeprowadzenie dwuetapowej zagłady ludności żydowskiej. Na Węgry przybyła jednostka specjalna Ordnungspolizei, dowodzona bezpośrednio przez Adolfa Eichmanna. Zarządzono gettoizację węgierskich miast. Żydzi zostali zamknięci w gettach, na ulicach panoszyli się strzałokrzyżowcy i zgodnie z planem Eichmanna rozpoczęły się masowe deportacje do Auschwitz. Pierwszy etap deportacji miał objąć społeczności żydowskie na prowincji, w drugim etapie zaplanowano deportowanie Żydów ze stolicy ${ }^{29}$.

Kontakty organizacji żydowskich w Szwajcarii i komitetu szwajcarsko-węgierskiego z działaczami żydowskimi w Budapeszcie stawały się coraz trudniejsze. Zaczęła się rwać korespondencja, poczta węgierska działała wolniej, listy nie docierały do żydowskich adresatów, przesyłki ginęły.

\section{Misja Floriana Manoliu}

Josef Mandl i jego brat gorączkowo szukali możliwości dostarczenia na Węgry pomocy. Coraz bardziej też martwili się o los swoich bliskich w stolicy i w Transylwanii. Mantello nie czekał już na listy nazwisk i fotografie do dokumentów. Polecił, aby biuro Mullera przygotowało około tysiąca certyfikatów in blanco. Bracia zwrócili się do rumuńskiego dyplomaty Floriana Manoliu, radcy handlowego w ambasadzie tego kraju w Bernie. Mieli do niego zaufanie, gdyż przed wojną był przez jakiś czas partnerem Josefa Mandla w interesach. Poprosili, żeby pojechał do Bukaresztu, a po drodze dostarczył działaczom żydowskim oraz szwajcarskiemu konsulowi w Budapeszcie Carlowi Lutzowi certyfikaty, leki i pieniądze, a także by odnalazł w okręgu Beszterce ich rodziców i siostry. Dla nich oraz dla bliskich i dalszych krewnych Mantello przygotował osobny pakiet ponad stu certyfikatów.

${ }^{28}$ Ibidem, s. 39-42; https://magdalenaandmonserratadventures.wordpress.com/2014/07/ 17/el-pasaporte-de-enrico/ (dostęp 11 IV 2019 r.).

${ }^{29}$ Kinga Piotrowiak-Junkiert, Gettoizacja Budapesztu 1944-1945. Zarys problemu, „Zagłada Żydów. Studia i Materiały" 2016, nr 12, s. 119-120. 
Manoliu podjął się misji i wystąpił do niemieckich oraz węgierskich władz o wizę tranzytową. Zgoda Berlina zwykle nadchodziła szybko, trudniej było o węgierską. Po 1940 r. ostry spór węgiersko-rumuński o Siedmiogród i wzajemne oskarżenia o dyskryminowanie mniejszości narodowych wzmogły stan wrogości między obu państwami, tlącej się od traktatu w Trianon. Włosko-niemiecka mediacja w 1942 r. w kwestii traktowania mniejszości węgierskiej w Rumunii i mniejszości rumuńskiej na Węgrzech niewiele pomogła. W 1943 r. na granicy rumuńsko-węgierskiej w Siedmiogrodzie doszło do krwawych incydentów i tylko polityczna presja Berlina zapobiegła wybuchowi wojny między dwoma sojusznikami Rzeszy. Wzajemna wrogość była tak silna, że Niemcy na froncie wschodnim musieli tak rozmieszczać dywizje rumuńskie i węgierskie, by ze sobą nie sąsiadowały. Manoliu wiedział, iż na węgierską wizę będzie musiał poczekać kilka dni, ale był przekonany, że ruszy w podróż w pierwszym tygodniu maja. Tym razem było inaczej. To Berlin bardzo długo zwlekał z odpowiedzią.

Dopiero 22 maja mógł wsiąść w pociąg do Wiednia. W podręcznym dyplomatycznym kufrze zamykanym na zamek szyfrowy wiózł certyfikaty, kilka pudełek antybiotyków i bilet wizytowy od znanego żydowskiego działacza Biura Palestyńskiego w Szwajcarii dr. Chaima Posnera z jego odręcznym hebrajskim dopiskiem, że okaziciel biletu jest osobą zaufaną. Na peronie wiedeńskiego dworca czekał na niego zaprzyjaźniony rumuński konsul urzędujący w tym mieście. Czekali także funkcjonariusze Gestapo, którzy oświadczyli rumuńskiemu dyplomacie, że zostaje zatrzymany, musi przerwać podróż i udać się z nimi do Berlina. Na szczęście tuż przed zatrzymaniem radca zdążył oddać bagaż w ręce kolegi. Kufer z certyfikatami pojechał do rumuńskiego konsulatu i został umieszczony w sejfie, a Bukareszt natychmiast otrzymał informację o akcji Gestapo.

Manoliu był przez kilka dni przesłuchiwany w siedzibie centrali Gestapo przy Prinz-Albrecht-Straße 8. Wywiad niemiecki podejrzewał, że radca pozostający w bliskich relacjach z Grigore Gafencu, byłym ministrem spraw zagranicznych Rumunii, przebywającym na wygnaniu w Genewie, oraz zaprzyjaźniony z Iuliu Maniu, rumuńskim ekspremierem i liderem krajowej opozycji wobec dyktatury marszałka Iona Antonescu, może być łącznikiem między nimi, a także ogniwem w tajnych negocjacjach rumuńsko-alianckich. Jakiś niemiecki agent w Szwajcarii zauważył jego kontakty z opozycją, a akcja Gestapo na dworcu w Wiedniu miała być finałem tajnej rozgrywki ujawniającej spisek.

Niemcy niczego się od Manoliu nie dowiedzieli i gdy rumuńskie MSZ w dość kategorycznym tonie upominało się o swojego dyplomatę, po ośmiu dniach go zwolnili. Pisemna instrukcja podróży, którą otrzymał od Gestapo i pod którą musiał się podpisać, nakazywała mu na podróż koleją w obie strony na trasie Wiedeń-Bukareszt bez prawa zatrzymywania się w Budapeszcie. Wrócił więc do Wiednia, odebrał z sejfu swój kufer i 3 czerwca wyjechał do stolicy swego kraju. W MSZ złożył dokładną relację o berlińskim przesłuchaniu. Spotkał się prywatnie z Iuliu Maniu, któremu przekazał wiadomości od Grigore Gafencu. W Bukareszcie pozostał jeszcze kilka dni. 
Rumun był człowiekiem odważnym i honorowym. Obiecał, że odnajdzie rodziców Mantella, by przekazać im bezpieczne dokumenty, i zamierzał się z tej obietnicy wywiązać, nie oglądając się na zakazy Gestapo. Pojechał do węgierskiego Siedmiogrodu. 10 czerwca dotarł do Beszterce, gdzie w getcie powinna się znajdować rodzina Mandlów wysiedlonych z Szászlekence. Ale getto w Beszterce było puste, na jednym z domów wisiała niewielka biała flaga z napisem Judenfrei. Od miejscowych dowiedział się, że dwa dni wcześniej wszyscy Żydzi 2 tys. osób - zostali załadowani do wagonów towarowych i wywiezieni z miasta.

Zaskoczyło go to i poruszyło. Nie zważając na niebezpieczeństwo zagrażające mu ze strony niemieckich i węgierskich patroli kontrolujących drogi i linie kolejowe, ufny, że paszport dyplomatyczny ochroni go w razie niebezpieczeństwa, przez tydzień odwiedzał kolejne miasta: Szatmárnémeti, (Satu-Mare), Dés (Dej), Marosvásárhely (Târgu Mureș), Nagyvarad (Oradea Mare). W żadnym z nich nie było już Żydów. W Kolosvarze, znanym mu z przedwojennych czasów, w dawnej dzielnicy żydowskiej, zamieszkanej niegdyś przez 17-tysięczną społeczność, natknął się tylko na poszukiwaczy żydowskich skarbów myszkujących w opustoszałych budynkach. Transylwańscy Żydzi zniknęli ${ }^{30}$.

Z tymi wiadomościami Manoliu wyruszył z Kolosvaru do Budapesztu. Liczył się z tym, że jego tygodniowa obecność w Siedmiogrodzie mogła nie ujść uwagi węgierskiej policji, strzałokrzyżowców i Gestapo. Nie znamy precyzyjnego terminarza misji podróży Manoliu. Jego itinerarium zostało już po wojnie odtworzone z dokładnością do dwóch dni. 17 lub 18 czerwca, po ośmiogodzinnej podróży, prosto $\mathrm{z}$ budapeszteńskiego dworca pojechał do rumuńskiego konsulatu przy ul. Horanszky 15, żeby zdeponować tam kufer z certyfikatami. Konsul generalny Joachim Daianu był zaskoczony, lecz gdy Manoliu wtajemniczył go w szczegóły swojej misji i opowiedział o dramatycznym rekonesansie po siedmiogrodzkich miastach w poszukiwaniu Żydów, którzy zniknęli bez śladu, bez wahania zadeklarował całkowite poparcie i pomoc. W swoim prywatnym apartamencie przy ul. Norymberskiej 50, który był bezpieczniejszym miejscem niż mogący znajdować się pod obserwacją budynek konsulatu, zorganizował spotkanie z wicekonsulem szwajcarskim Carlem Lutzem oraz działaczem syjonistycznym Miklósem Krauszem, kierującym budapeszteńskim Biurem Palestyńskim. Manoliu przekazał im otrzymane od Mantella certyfikaty, lekarstwa i pieniądze.

Krausz był nieufny i nie chciał tego spotkania. Nie znał ani Manoliu, ani Mantella. Obawiał się, że to prowokacja Gestapo, próbującego rozpoznać i przejąć kanały łączności między organizacjami żydowskimi na Węgrzech i w Szwajcarii. Przekonał go do Rumuna bilet wizytowy Posnera z jego hebrajskim dopiskiem. Mimo to ich spotkanie nie było efektywne. Manoliu kiepsko znał węgierski, a jego rozmówca nie mówił po rumuńsku ani francusku. Zdesperowany Krausz chciał, by Manoliu wywiózł z Budapesztu informacje o dramatycznej sytuacji Ży-

${ }^{30}$ Mordecai Paldiel, Diplomat Heroes of the Holocaust, Jersey City: Ktav Pub \& Distributors Inc, 2007, s. 171-173. 
dów węgierskich. 19 czerwca do apartamentu rumuńskiego konsula dostarczył dwa maszynopisy, które jego żona przepisywała przez całą noc. Pierwszym była kopia „Auschwitz Protocols” opracowanych przez Rudolfa Vrbę (Waltera Rosenberga) i Josefa Lanika (Alfreda Wetzlera), drugim zaś raport opisujący szczegółowo, miasto po mieście, trwającą deportację 435 tys. Żydów węgierskich do Auschwitz ${ }^{31}$.

Manoliu, wstrząśnięty otrzymanymi informacjami, najbliższym pociągiem wyruszył do Szwajcarii. Późnym wieczorem 20 czerwca, tuż po przekroczeniu granicy zadzwonił do genewskiego hotelu, w którym mieszkali Mantello i jego brat, by dać im znać, że ma bardzo złe wiadomości i powinni się spotkać, gdy tylko dotrze do Genewy. Spotkali się o drugiej w nocy. Powiedział braciom o tragicznym losie ich rodziców i krewnych z Beszterce - ponadstuosobowego rodzinnego klanu - deportowanych do Auschwitz. Lepsze były informacje o Irene Berger. Została opiekunką grupy dzieci żydowskich, którą wziął pod swoją ochronę szwajcarski konsulat. Rumunowi nie udało się z nią spotkać, za to Lutz zorganizował mu spotkanie z jej ojcem Ignazem Bergerem, mieszkającym w pobliżu konsulatu.

Reszta wiadomości była jeszcze tragiczniejsza. Manoliu zrelacjonował braciom swoje obserwacje z podróży po Transylwanii i przekazał wszystkie informacje o deportacjach oraz sytuacji Żydów w Budapeszcie, jakich udzielili mu Lutz i Krausz. Przede wszystkim zaś oddał w ich ręce maszynopisy otrzymane od Krausza wraz z jego listem przewodnim, zawierającym dramatyczne błaganie świata o pomoc. Tej nocy wszyscy trzej mieli jasność, że lada moment esesmani Eichmanna i policjanci Horthyego wyślą do Auschwitz lub wymordują na miejscu 300 tys. Żydów z Budapesztu i okolic. Społeczność żydowska na Węgrzech przestanie istnieć i świat nawet tego nie zauważy ${ }^{32}$.

\section{Kampania prasowa Mantella}

Przez następne dni bracia działali jak w gorączce. Mantello wezwał do biura studentów z grupy Mullera. Od rana w środę 21 czerwca sześciu studentów zaczęło tłumaczyć na język niemiecki dokumenty przywiezione przez Manoliu. Żeby było szybciej, pracowali w parach, z których każda tłumaczyła inny fragment tekstu. W jednym z genewskich hoteli Mantello załatwił dostęp do maszyny powielającej Gestetner i po południu wysłał tam dwóch studentów z kompletną wersją przekładu. Wieczorem miał już pierwsze pięćdziesiąt egzemplarzy „Auschwitz Protocols”. W następnych godzinach liczba studentów związanych z Mantellem i Mullerem pracujących nad tłumaczeniami wzrosła do trzydziestu. W czwartek były gotowe kompletne wersje w języku angielskim i francuskim. Przekład hiszpański sporządził opłacony przez Mantella zawodowy tłumacz

\footnotetext{
${ }^{31}$ Ibidem, s. 174-176; Kranzler, The Man Who Stopped the Trains to Auschwitz..., s. 82-84.

${ }^{32}$ Kanzler, The Man Who Stopped the Trains to Auschwitz..., s. 88-89.
} 
związany z konsulatem, gdyż żaden ze studentów nie znał tego języka wystarczająco dobrze ${ }^{33}$.

W trybie alarmowym bracia poprosili o spotkanie w Zurichu z komitetem rabinów szwajcarskich oraz członkami komitetu szwajcarsko-węgierskiego. Mantello wręczył im egzemplarze „Auschwitz Protocols”, a ich lektura wstrząsnęła wszystkimi. „To jak zburzenie Drugiej Świątyni” - miał powiedzieć rabin Kornfein. „To nic innego jak rumuńska propaganda” - replikował Geza Pallai, jedyny członek SHC, który nie dał wiary dokumentom. Ostro zaatakowany przez Mantella, zrezygnował wkrótce z członkostwa w SHC. Pozostali uczestnicy spotkania zadeklarowali pełną gotowość do działania w ramach planu, jaki przedstawił im Mantello. On też rozdzielił pomiędzy nich zadania.

Rabin Kornfein wziął na siebie kontakty z Kościołem protestanckim, przede wszystkim z pastorem Vogtem, z którym - podobnie jak Mantello - pozostawał w przyjaznych relacjach. Michaly Banyai z SHC miał przekazać egzemplarze „Auschwitz Protocols" amerykańskiemu dyplomacie Roswellowi McClellandowi, reprezentującemu powołaną w styczniu 1944 r. przez prezydenta Roosevelta Radę ds. Uchodźców Wojennych. Mantello nie ufał mu i uważał go za nieprzychylnie nastawionego wobec żydowskich problemów. Sam podjął się jak najszerszego rozkolportowania przetłumaczonych dokumentów. Studenci z jego biura rozsyłali dokumenty do placówek dyplomatycznych, do kościołów, redakcji i urzędów ${ }^{34}$.

Za pośrednictwem Castellanosa „Auschwitz Protocols” otrzymał sędzia Guerrero, który - przez ambasadora Szwecji - miał przekazać informację o nich królowi Gustawowi V, a także wysoko postawionym urzędnikom watykańskim. Informacje o Auschwitz i zagładzie Żydów przywiezione z Węgier przez Manoliu wcześniej docierały na Zachód i były już znane wielu przywódcom politycznym. Znane były też Stolicy Apostolskiej i sędzia Guerrero niczego nowego swoim watykańskim znajomym nie powiedział. Co więcej, wiedza ta była objęta wewnętrzną cenzurą polityczną, nie docierała do szerokiej opinii publicznej i nie owocowała zdecydowanymi reakcjami politycznymi i dyplomatycznymi ${ }^{35}$.

Właśnie dotarcie z tą wiedzą do światowej opinii publicznej mogło mieć kluczowe znaczenie i z tego Mantello zdawał sobie w pełni sprawę. W czwartek późnym wieczorem spotkał się z komandorem Westem, przekazał mu egzemplarz dokumentów i poprosił o pomoc. W piątek redakcje prasowe w Wielkiej Brytanii i Stanach Zjednoczonych otrzymały obszerną depeszę opartą na dokumentacji

${ }^{33}$ Jedna z par tłumaczy w pośpiechu popełniła w swoim fragmencie błąd, który stał się potem przedmiotem dociekań historyków. W wykazie państw, z których Żydzi trafiali do Auschwitz, pominęli oni Litwę oraz liczbę zamordowanych 50 tys. Żydów z tego kraju. Tym samym liczba 1765000 zamordowanych Żydów podana w oryginale „Auschwitz Protocols” we wszystkich kopiach powstałych w biurze Mantella wynosi 1715000.

${ }^{34}$ Kranzler, The Man Who Stopped the Trains to Auschwitz..., s. 92.

${ }^{35}$ José Miguel Arévalo-Rengifo, El salvadoreño que trascendió las fronteras: dr. José Gustavo Guerrero, San Salvador: J.M. Arévalo-R., 2010, s. 129-130. 
Krausza. Nadawcą był dziennikarz Walter Garrett, dyrektor genewskiego biura agencji prasowej British Exchange Telegraph. Garrett był nie tylko dziennikarzem, pracował także pod kierunkiem Westa dla brytyjskiego wywiadu. Za pośrednictwem Westa i Garretta informacje od Mantella trafiły niemal natychmiast do Allena Dullesa, kierującego amerykańskim wywiadem na Europę ${ }^{36}$.

Akcja Mantella zmieniła sytuację. Głos zabrał szwajcarski Kościół protestancki i jego dwaj najwybitniejsi wówczas teologowie, prof. Karl Barth oraz pastor Paul Vogt. Vogt spotkał się 25 czerwca z Mantellem i zapytał go, czy osobiście gwarantuje wiarygodność „Auschwitz Protocols”. Usłyszał takie zapewnienie i zgodził się być twarzą kościelnego sprzeciwu. Słowa potępienia Holokaustu padające $\mathrm{z}$ ambon podczas specjalnych nabożeństw zmobilizowały szwajcarskich chrześcijan, wywołały masowe wiece protestacyjne, podczas których krytykowano obojętność rządu szwajcarskiego i Czerwonego Krzyża. Pod ścianą znalazł się Kościół katolicki. Watykański chargé d'affaires w Szwajcarii Giuseppe Burzio przekazał swoim szefom uwagę swego węgierskiego przyjaciela Mantella, iż szwajcarska protestancka opinia publiczna może dojść do wniosku, że Kościół katolicki nie czyni nic, by pomóc uratować Żydów ${ }^{37}$.

Cenzura nie mogła już powstrzymać prasy. W szwajcarskich gazetach ukazało się kilkaset artykułów potępiających prześladowania i deportacje Żydów do Auschwitz oraz współudział Węgier w tej zbrodni. Publikacje te znalazły ogromny oddźwięk w prasie światowej. McClelland - bardzo ostrożny, jeśli nie wręcz sceptyczny wobec informacji Krausza - i jego pracownicy zgromadzili wówczas najkompletniejszy zbiór wycinków prasowych, obejmujący ponad 400 artykułów. To musiało zrobić w Departamencie Stanu wrażenie ${ }^{38}$.

Pękła zmowa milczenia. Kampania informacyjna Mantella stała się kamieniem, który poruszył lawinę. Wstrząsnęła światową opinią publiczną i zmusiła rządy do działania. Publicznie zaprotestowali papież, prezydent Roosevelt, brytyjski minister spraw zagranicznych Anthony Eden, król Szwecji i Międzynarodowy Czerwony Krzyż. Światowa presja tak przestraszyła admirała Horthyego, że polecił wstrzymać transporty do Auschwitz. Pociągi, którymi od 15 maja 1944 r. wywożono z Węgier codzienne 12 tys. Żydów, zostały wstrzymane 9 lipca.

${ }^{36}$ Paul Bogdanor, Kasztner's Crime, London-New York: Routledge, 2016, s. 187-189; Anthony Grenville, The Integration of Aliens: The Early Years of the Association of Jewish Refugees Information, 1946-1950, „German-speaking Exiles in Great Britain” 1999, t. 2, s. 5-7. Garrett opisał swój udział w operacjach specjalnych podczas drugiej wojny światowej w książce The Secret History of PWE. The Political Warfare Executive 1939-1945 (London: St Ermin's, 2002).

${ }^{37}$ Kranzler, The Man Who Stopped the Trains to Auschwitz..., s. 292-293.

${ }^{38}$ David Kranzler, Thy Brother's Blood: The Orthodox Jewish Response During the Holocaust, New York: Mesorah Publications Ltd., 1987, s. 104-105. 


\section{Uznanie salwadorskich certyfikatów}

Na Węgrzech rozpoczęła się gorączkowa międzynarodowa akcja ratunkowa, która miała swoich wielkich bohaterów: Szweda Raula Wallenberga, Szwajcara Karla Lutza oraz dwóch hierarchów watykańskich - nuncjusza abp. Angela Rotta i sekretarza nuncjatury abp. Gennara Verolina ${ }^{39}$. Ich narzędziem były paszporty i certyfikaty obywatelstwa państw neutralnych. Wallenberg wystawił paszporty dla około 10 tys. Żydów. Obaj arcybiskupi z budapeszteńskiej nuncjatury dostarczyli mu fałszywe paszporty watykańskie i tysiące fałszywych metryk chrztu. Z Genewy, m.in. za pośrednictwem kolejarzy, przesyłano na Węgry setki salwadorskich certyfikatów in blanco produkowanych w biurze Mantella.

W maju 1944 r. w Salwadorze upadła dyktatura gen. Hernándeza. W wyniku demokratycznych - jak na tamtejsze warunki - wyborów władzę objął prezydent Castaneda Castro. Pułkownik Castellanos oficjalnie poinformował go, że na terytorium Węgier znajduje się co najmniej kilkanaście, jeśli nie kilkadziesiąt, tysięcy Żydów posiadających dokumenty potwierdzające ich salwadorskie obywatelstwo. Nowy prezydent zaakceptował ten fakt i zwrócił się o ich ochronę do Międzynarodowego Czerwonego Krzyża.

Większość „salwadorskich” Żydów w Budapeszcie ocalała, znalazłszy schronienie w „bezpiecznych domach” organizowanych przez Wallenberga i Lutza. Do jednego z nich, „szklanego domu” przy ul. Vadász 29, zorganizowanego w budynku magazynowym oddanym Lutzowi przez rodzinę Weischów, największych węgierskich importerów szkła, trafiła żona Mantella. I przeżyła budapeszteńską apokalipsę.

Z powodu zakamuflowanego systemu ewidencji certyfikatów salwadorskich nie jest znana dokładna liczba dokumentów wystawionych przez Castellanosa i Mantella. Przyjmuje się, że powstało ich ponad 13 tys. Tym trudniej ustalić liczbę osób, które były nimi chronione, skoro większość certyfikatów była wystawiana na całą rodzinę. Prasa salwadorska chętnie pisze dzisiaj, że dzięki Castellanosowi ocaliło życie około 40 tys. nowych obywateli Salwadoru, który liczył w tym czasie 1,6 mln ludności.

\section{Powojenne losy}

Wraz z zakończeniem działań wojennych w Europie drogi Castellanosa i Mantella się rozeszły. Pułkownik zakończył oficjalnie swoją misję dyplomatyczną w Genewie 1 października 1945 r. Został mianowany ambasadorem w Londynie i na nową placówkę pojechał już z Marią Schurmann, którą poślubił jeszcze w Genewie. Do kraju odwołano go po dwóch latach - gdy emocje pierwszych powojennych miesięcy opadły, w San Salwador przypomniano sobie o niesub-

${ }^{39} \mathrm{O}$ tej akcji, podając te i inne jeszcze nazwiska jej bohaterów oraz ich noty biograficzne, pisze Kinga Piotrowiak-Junkiert (eadem, Gettoizacja Budapesztu..., s. 126-136). 
ordynacji pułkownika, który nie stosował się do poleceń swego rządu, a wręcz je łamał. Odesłano go na emeryturę. Maria urodziła mu trzy córki: Friedę, Yvone i Blancę, ale nie było im dane żyć spokojnie.

W 1948 r. prezydenta Castenadę Castro odsunął od władzy pucz wojskowy, a junta pułkowników Óscara Osoria i José Maríi Lemusa uznała Castellanosa za wroga. Musiał opuścić kraj i przez kilka lat przebywał na emigracji w Gwatemali i Meksyku. Wrócił do San Salwador pod koniec lat pięćdziesiątych i dożył tam sędziwego wieku w całkowitym zapomnieniu. Za życia o jego wojennych zasługach nie pamiętano i nie interesowano się jego historią. W 1955 r. artykuł o „Salwadorczyku, który uratował tysiące Żydów”, ukazał się w „Jewish Observer”, ale nie odbił się wówczas większym echem ${ }^{40}$. W 1976 r. Castellanos opowiedział o swoim udziale w ratowaniu Żydów w krótkim wywiadzie dla stacji Radio Nacional. Kilka miesięcy później zmarł ${ }^{41}$. Dopiero w 2010 r. został uhonorowany tytułem Sprawiedliwego wśród Narodów Świata.

George Mantello pozostał w Szwajcarii i zajął się interesami. Gdy pod koniec lat czterdziestych zmarła jego pierwsza żona Irene Berger, ożenił się ponownie. $Z$ drugą żoną miał dwoje dzieci - syna i córkę, ale małżeństwo nie przetrwało. W 1953 r. przeniósł się do Włoch, a jego syn Enrico twierdził później, że do opuszczenia Szwajcarii zmusiło ojca ustawiczne nękanie ze strony Heinricha Rothmunda, który aż do 1954 r. pozostawał na stanowisku szefa policji. Kilkakrotnie usiłował on wszcząć postępowanie karne lub deportacyjne wobec Mantella, zarzucając mu fałszowanie i stworzenie „czarnego rynku” dokumentów paszportowych, a także nadużywanie immunitetu dyplomatycznego.

W 1988 r. Mandel-Mantello z rąk burmistrza Nowego Jorku Edwarda I. Kocha otrzymał medal Eleonor Roosevelt za zasługi w obronie praw człowieka, a nowojorski Yeshiva University nadał mu tytuł doktora honoris causa. Zmarł 25 kwietnia 1992 r. w Rzymie w wieku 90 lat. Pochowano go na cmentarzu Har Hamenuchot w Jerozolimie ${ }^{42}$.

José Gustavo Guerrero został po wojnie pierwszym przewodniczącym Międzynarodowego Trybunału Sprawiedliwości w Hadze, który Narody Zjednoczone powołały na miejsce przedwojennego trybunału. Dwukrotnie - w 1948 i 1949 r. - nominowano go do Pokojowej Nagrody Nobla. Stał na czele MTS do 1949 r., a później pozostał w trybunale jako jego sędzia aż do śmierci w 1958 r., w wieku 82 lat $^{43}$.

\footnotetext{
${ }^{40}$ Jon Kimche, The war's unpaid dept of honour. How El Salvador saved tens of thousands of Jews, „Jewish Observer and Middle East Review” 1955, nr 4.

${ }^{41} \mathrm{http}$ ///www.elsalvadormipais.com/jose-arturo-castellanos (dostęp 11 IV 2019 r.).

${ }^{42}$ Lee A. Daniels, George Mandel-Montello Is Dead, „The Times”, 6 V 1992, s. 16.

${ }^{43}$ Ricardo Gallardo, In Memoriam; Jose Gustavo Guerrero, „Revista Española de Derecho Internacional” 1959, t. 12, nr 1/2, s. 159-180; Ramón López Jiménez, Biografía del Dr. José Gustavo Guerrero, Biblioteca „Dr. José Gustavo Guerrero”, San Salwador, 2016, Press release, w zbiorach autora.
} 
Florian Manoliu pozostawał w rumuńskiej służbie dyplomatycznej do $1947 \mathrm{r}$. Po abdykacji króla Michała I oraz utworzeniu Rumuńskiej Republiki Ludowej, zagrożony komunistycznymi represjami, zbiegł z kraju i poprosił o azyl polityczny w Szwajcarii.

We wrześniu 1951 r. przeniósł się do Argentyny. Z drugą żoną Elwirą mieszkał w Bahia Blanca. Na tamtejszym uniwersytecie (Universidad Nacional del Sur) wykładał ekonomię i przez kilka lat był jego wicekanclerzem. Cieszył się wielką sympatią studentów oraz szacunkiem i prestiżem w kręgach miejscowej elity, do czego przyczyniała się jego osobista znajomość z gen. Juanem Peronem. Zmarł w Buenos Aires 23 kwietnia 1977 r. w szpitalu podczas operacji serca. Jego córka z pierwszego małżeństwa Dominga mieszka w Europie ${ }^{44}$. Tytuł Sprawiedliwego wśród Narodów Świata otrzymał w 2001 r.

\section{BIBLIOGRAFIA}

\section{Literatura przedmiotu}

Arévalo-Rengifo José Miguel, El salvadoreño que trascendió las fronteras: dr. José Gustavo Guerrero, San Salvador: J.M. Arévalo-R., 2010.

Arévalo-Rengifo José Miguel, La vida de Dr. José Gustavo Guerrero 1876-1958. El salvadoreño que trascendió las fronteras, San Salvador: Imprenta Jaime, 2010.

Biografie Gheorghe Drăgănescu, Agenției de Informații Geospațiale a Apărării „General de divizie Constantin Barozzi".

Bogdanor Paul, Kasztner's Crime, London-New York: Routledge, 2016.

Cancilleria presenta segunda edicion del libro „Cnel. José Arturo castellanos, Heroe del Holocausto”, Ministerio de Relaciones Exteriores de El Salvador, Press release, 18 VII 2011 r., w zbiorach autora.

Castellanos de García Frieda, [Wywiad], „La Nacion”, 5 VI 2011.

Cnel. José Arturo Castellanos: Héroe del Holocausto, San Salvador: Ministerio de Relaciones Exteriores de El Salvador, 2010.

Daniels Lee A., George Mandel-Montello Is Dead, „The Times”, 6 V 1992.

Galambos Eva, Un dyplomat Roman a ajutat la salvarea evreilor din Budapesta, „Revista Baabel” 2015, nr 6, https://baabel.ro/2015/06/un-diplomat-roman-a-ajutat-lasalvarea-evreilor-din-budapesta/.

Gallardo Ricardo, In Memoriam; Jose Gustavo Guerrero, „Revista Española de Derecho Internacional" 1959, t. 12, nr 1/2.

${ }^{44}$ Gustavo Mandará, Florín Manoliú: el hombre que no podía ser espectador, „La Nueva Provincia", 3 X 2004, s. 11-14; Eva Galambos, Un dyplomat Roman a ajutat la salvarea evreilor din Budapesta, „Revista Baabel” 2015, nr 6, https://baabel.ro/2015/06/un-diplomat-roman-a-ajutat-la-salvarea-evreilor-din-budapesta/ (dostęp 11 IV 2019 r.). W lutym 2019 r. Uniwersytet Aleksandra Jana Cuzy w Jassach zorganizował konferencję naukową poświęconą dyplomacji rumuńskiej w latach drugiej wojny światowej. Historyk z Archiwum Ministerstwa Spraw Zagranicznych Rumunii dr Florin C. Stan przedstawił referat „Florian Manoliu - diplomat atipic, între loialitatea față de țară și datoria față de concetățenii săi" (Florian Manoliu - nietypowy dyplomata, między lojalnością wobec kraju a obowiązkiem wobec współobywateli), którego naukowo opracowana wersja ukaże się drukiem najprawdopodobniej pod koniec $2020 \mathrm{r}$. 
Garrett Walter, The Secret History of PWE. The Political Warfare Executive 1939-1945, London: St Ermin's, 2002.

Grenville Anthony, The Integration of Aliens: The Early Years of the Association of Jewish Refugees Information, 1946-1950, „German-speaking Exiles in Great Britain” 1999 , t. 2.

Grupa Berneńska - dyplomaci Rzeczypospolitej Polskiej z pomocą Żydom. Wystapienie ambasadora RP w Szwajcarii dr. Jakuba Kumocha, wygłoszone 4 lutego 2018 r. w Muzeum Pamięci Shoah w Paryżu, „Polski Przegląd Dyplomatyczny” 2018, nr 2.

Haska Agnieszka, „Jestem Żydem, chcę wejśc”. Hotel Polski w Warszawie 1943, Warszawa: Centrum Badań nad Zagładą Żydów i Wydawnictwo IFiS PAN, 2006.

Haska Agnieszka, „Proszę Pana Ministra o energiczna interwencję”. Aleksander Ładoś (1891-1963) i ratowanie Żydów przez Poselstwo RP w Bernie, „Zagłada Żydów. Studia i Materiały" 2015, nr 11.

Kimche Jon, The war's unpaid dept of honour. How El Salvador saved tens of thousands of Jews, „Jewish Observer and Middle East Review” 1955, nr 4.

Kranzler David, The Man Who Stopped the Trains to Auschwitz: George Mantello, El Salvador, and Switzerland's finest hour, Syracuse, NY: Syracuse University Press, 2000.

Kranzler David, Thy Brother's Blood: The Orthodox Jewish Response During the Holocaust, New York: Mesorah Publications Ltd., 1987.

Kumoch Jakub, Państwo polskie ratowało Żydów. Polemika z dr Agnieszkq Haska, „Gazeta Wyborcza”, 7 I 2019, dodatek „Ale Historia”, nr 1.

López Jiménez Ramón, Biografía del Dr. José Gustavo Guerrero, Biblioteca „Dr. José Gustavo Guerrero", San Salwador, 2016, Press release, w zbiorach autora.

Mandará Gustavo, Florín Manoliú: el hombre que no podía ser espectador, „La Nueva Provincia", 3 X 2004.

Nowotnik Norbert, Paszporty Paragwaju, czyli działalność Grupy Berneńskiej, „Kombatant” 2019, nr 3.

Otwarte niebo. Spotkanie panelowe, Polskie Zakłady Lotnicze, Baranów, 2 XII 1999 r., materiały konferencyjne w zbiorach autora.

Paldiel Mordecai, Diplomat Heroes of the Holocaust, Jersey City: Ktav Pub \& Distributors Inc, 2007.

Piotrowiak-Junkiert Kinga, Gettoizacja Budapesztu 1944-1945. Zarys problemu, „Zagłada Żydów. Studia i Materiały” 2016, nr 12.

Polsko-rumuńska komisja graniczna, „Światowid. Ilustrowany Kurjer Cotygodniowy”, 23 IV 1927.

Potocki Michał, Zbigniew Parafianowicz, Polak na polecenie rzq̨du ratował Żydów od Holokaustu. Świat się o tym nie dowiedział, „Dziennik Gazeta Prawna”, 7 VIII 2017.

Reid Pat, Winged Diplomat: The Life Story of Air Commodore „Freddy”, London: Chatto and Windus, 1962.

Stan Florin C., „Florian Manoliu - diplomat atipic, între loialitatea față de țară și datoria față de concetățenii săi", referat wygłoszony w lutym 2019 r. podczas konferencji Uniwersytecie Aleksandra Jana Cuzy w Jassach.

Un Salvadoreño en la historia del pueblo judío, „Long Island Al Día”, 10 IX 2010.

Wywiad Pawła Smoleńskiego z dr Agnieszką Haską, „Gazeta Wyborcza”, 17 XII 2018, dodatek „Ale Historia”, nr 49.

Zometa Jose, La historia ha consagrado al Dr. Guerrero como inmortal, „El Diario de Hoy”, 16 X 2018. 


\section{Strony internetowe}

https://www.aciprensa.com/noticias/la-historia-del-catolico-de-el-salvador-que-salvo40-mil-judios-del-holocausto-78277

http://www.elsalvadormipais.com/jose-arturo-castellanos

https://magdalenaandmonserratadventures.wordpress.com/2014/07/17/el-pasaporte-de-enrico/

https://math.dartmouth.edu/ lamperti/Holocaust_Heroes.pdf

https://www.polskieradio.pl/5/3/Artykul/2025372,Ambasador-Polski-w-SzwajcariiPolacy-pomagali-przy-wykupie-Zydow-z-rak-nazistow-Alianci-byli-temu-przeciwni http://www.raoulwallenberg.net/saviors/diplomats/list/george-mandel-mantello-485/ https://www.warhistoryonline.com/history/jose-arturo-castellanos-contreras-latinoschindler.html

https://wpolityce.pl/historia/377271-zapomniana-karta-z-dziejow-polskiej-pomocyzydom-falszywe-paszporty-ratowaly-zycie-setkom-ludzi 
